\title{
OPEN Survey and characterization of nonfunctional alleles of FUT2 in a database
}

\author{
Mikiko Soejima \& Yoshiro Koda ${ }^{凶}$
}

The expression of $A B O$ antigens in human saliva is regulated by the FUT2 gene, which encodes a secretor type $\alpha(1,2)$ fucosyltransferase. Secretors express ABO substrates in saliva and non-secretors do not. Secretor status is an object of concern, especially for susceptibility to various infectious diseases. A multitude of single nucleotide polymorphisms (SNPs) and copy number variations (CNVs) have been reported, and they show unique distributions among different populations. In this study, we selected 18 uncharacterized FUT2 alleles listed in the Erythrogene database and obtained genomic DNA having these alleles. We experimentally confirmed the haplotypes, but 10 of 18 alleles disagreed with those in the database, which may be attributed to their low frequency. We then examined the activity of the encoded $\alpha(1,2)$ fucosyltransferase for 13 alleles by flow cytometry of $H$ antigen expression. The impact of each nonsynonymous SNP on the enzyme was also estimated by software. We finally identified two non-secretor alleles $\left(s e^{610}\right.$ and $\left.s e^{357,856,863}\right)$ and one weak secretor allele $\left(s e^{262,357}\right)$, while in silico analysis predicted that many alleles impair the function. The present results suggest that correct haplotyping and functional assays are desirable for analysis of the FUT2 gene.

The human FUT2 encodes the secretor type $\alpha(1,2)$ fucosyltransferase. This enzyme participates in synthesis of the $\mathrm{H}$ antigen, which is a precursor of $\mathrm{A}$ and $\mathrm{B}$ blood group antigens, on the surface of mucosa or in secretions. Secretor status is dominant over non-secretor status, and therefore the presence of at least one functional FUT2 allele $(\mathrm{Se})$ results in the secretor phenotype, while the non-secretors are homozygotes of the null alleles ( $s e$ ) and lack $\mathrm{ABH}$ antigens in saliva and other body fluids. Weak-secretors are homozygotes of the weak-secretor allele $\left(\mathrm{Se}^{w}\right.$, see Table 1) or heterozygotes of $\mathrm{Se}^{w} /$ se and express lower amounts of these antigens than secretors do ${ }^{1,2}$.

The prevalence of non- or weak secretors is about $20-25 \%$ in most geographic regions, and statistical analysis of genetic variations of this locus suggest that the relative frequencies of secretors and non-secretors (or weak secretors) have been maintained for a long time by balancing selection, and that various pathogens may be considered an important selective force ${ }^{3,4}$.

The coding sequence of FUT2 is not interrupted by an intron and locates solely in the second exon, which encodes a 343-amino acid protein. This makes it easy to determine the haplotypes of SNPs of the protein coding region ${ }^{5,6}$. Because we numbered the nucleotide positions of FUT2 using a short coding region (999 bp: 332 amino acids) in previous studies ${ }^{3,7}$, we also used this to describe SNPs or alleles for easy comparison, while we used a long coding region (1032 bp: 343 amino acids) that has an additional $33 \mathrm{bp}$ at the $5^{\prime}$-region for in silico analyses only to predict the impact of SNPs on the protein.

Because the blood group antigens on the surface of mucosa or in secretions can be used as a scaffold for infection by some kinds of pathogens, secretor status has been reported to be associated with susceptibility to viruses such as norovirus and rotavirus ${ }^{8,9}$. In addition, genome-wide association studies revealed its association with Crohn's disease, celiac disease, and inflammatory bowel disease $\mathrm{e}^{10,11}$

Many single nucleotide polymorphisms (SNPs) and recombinant null alleles have been identified so far ${ }^{4,12-16}$. Representative SNPs and their alleles are shown in Table 1. Interestingly, some of them are distributed in a population-specific pattern. For association studies on secretor status, we need to know the genetic background of FUT2 of the target populations unless we can determine the secretor status by phenotype. However, because amino acid substitutions do not always affect the activity of the encoded Se enzyme, predicting it is sometimes difficult ${ }^{17-19}$. To examine the impact of each of the SNPs on the enzyme activity, we can monitor the $\alpha(1,2)$ fucosyltransferase activity by transient expression in cultured cells, followed by measurement of the enzyme activity using ${ }^{14} \mathrm{C}$-labeled fucose or its acceptor or examination of the $\mathrm{H}$ antigen on the cell surface by flow cytometry $^{17,20,21}$. 


\begin{tabular}{|c|c|c|c|}
\hline Allele & SNPs & Amino acid changes & Populations \\
\hline \multicolumn{4}{|c|}{ Secretor alleles } \\
\hline $\mathrm{Se}$ & & No change & Various populations \\
\hline $\mathrm{Se}^{40}$ & $40 \mathrm{~A}>\mathrm{G}$ & I14V & Africans, Puerto Ricans \\
\hline$S e^{278,357}$ & $\begin{array}{l}278 \mathrm{C}>\mathrm{T} \\
357 \mathrm{C}>\mathrm{T}\end{array}$ & A93V & Iranians, Sri Lankans, Israelis \\
\hline$S e^{357}$ & $357 \mathrm{C}>\mathrm{T}$ & No change & Various populations \\
\hline $\mathrm{Se}^{357,480}$ & $357 \mathrm{C}>\mathrm{T} 480 \mathrm{C}>\mathrm{T}$ & No change & Africans, South and East Asians, Europeans \\
\hline $\mathrm{Se}^{375}$ & $375 \mathrm{~A}>\mathrm{G}$ & No change & New Guineans, African, Samoans \\
\hline $\mathrm{Se}^{400}$ & $400 \mathrm{G}>\mathrm{A}$ & V134I & New Guineans, Samoans \\
\hline$S e^{481}$ & $481 \mathrm{G}>\mathrm{A}$ & D161N & Africans \\
\hline \multicolumn{4}{|c|}{ Nonsecretor or weak-secretor alleles } \\
\hline$s e^{302}$ & $302 \mathrm{C}>\mathrm{T}$ & I101P & South Asians, Peruvians \\
\hline$s e^{357,385 *}$ & $385 \mathrm{~A}>\mathrm{T}$ & I129F & East and Southeast Asians (50\%) \\
\hline$s e^{357,571}$ & $357 \mathrm{C}>\mathrm{T} 571 \mathrm{C}>\mathrm{T}$ & R191X & Samoans, Taiwanese \\
\hline$s e^{357,480,778 d e l}$ & $357 \mathrm{C}>\mathrm{T} 480 \mathrm{C}>\mathrm{T}$ 778delC & 259fs275X & Africans \\
\hline$s e^{428}$ & $428 \mathrm{G}>\mathrm{A}$ plus 4 & W143X & $\begin{array}{l}\text { Europeans, Africans, West Asians (50\%), South Asians, Latin Ameri- } \\
\text { cans }\end{array}$ \\
\hline$s e^{628}$ & $628 \mathrm{C}>\mathrm{T}$ & $\mathrm{R} 210 \mathrm{X}$ & Taiwanese \\
\hline$s e^{841}$ & $841 \mathrm{G}>\mathrm{A}$ & Q292R & Peruvians \\
\hline$s e^{849}$ & $849 \mathrm{G}>\mathrm{A}$ & W283X & Taiwanese \\
\hline
\end{tabular}

Table 1. Distribution of SNPs and alleles of FUT2 in various populations. ${ }^{\star}$ Represents weak secretor allele $\left(S e^{w}\right)$.

The 1000 Genome Project (https://www.internationalgenome.org/) is the largest public catalogue of human variation and genotype data ${ }^{22}$. Erythrogene v0.8 (27 Nov 2017) (http://www.erythrogene.com/) extracted the data of blood group alleles from 1000 Genomes and matched them against blood group reference lists ${ }^{23}$. For FUT2, 73 alleles are listed at present. To survey the uncharacterized nonfunctional alleles of FUT2, we selected 18 alleles listed in Erythrogene (80T $>\mathrm{C}$; 357C $>\mathrm{T}$; 385A $>\mathrm{T}$, 357C $>\mathrm{T}$; 403C $>\mathrm{T}$; 950C $>\mathrm{T}, 357 \mathrm{C}>\mathrm{T}$; $964 \mathrm{~A}>\mathrm{G}, 357 \mathrm{C}>\mathrm{T}$; $385 \mathrm{~A}>\mathrm{T} ; 539 \mathrm{G}>\mathrm{A}, 357 \mathrm{C}>\mathrm{T} ; 610 \mathrm{G}>\mathrm{T}, 40 \mathrm{~A}>\mathrm{G} ; 357 \mathrm{C}>\mathrm{T} ; 616 \mathrm{G}>\mathrm{C}, 357 \mathrm{C}>\mathrm{T} ; 715 \mathrm{C}>\mathrm{T}, 357 \mathrm{C}>\mathrm{T} ; 856 \mathrm{~T}>\mathrm{C} ; 863 \mathrm{C}>\mathrm{T}$, $370 \mathrm{G}>\mathrm{A}, 58 \mathrm{C}>\mathrm{T} ; 357 \mathrm{C}>\mathrm{T}, 357 \mathrm{C}>\mathrm{T} ; 566 \mathrm{~T}>\mathrm{C}, 418 \mathrm{G}>\mathrm{A} ; 863 \mathrm{C}>\mathrm{T}, 357 \mathrm{C}>\mathrm{T} ; 980 \mathrm{C}>\mathrm{A}, 357 \mathrm{C}>\mathrm{T} ; 385 \mathrm{~A}>\mathrm{T} ; 980 \mathrm{C}>\mathrm{A}$, $357 \mathrm{C}>\mathrm{T} ; 544 \mathrm{G}>\mathrm{A} ; 771 \mathrm{G}>\mathrm{A}, 205 \mathrm{G}>\mathrm{A} ; 357 \mathrm{C}>\mathrm{T}, 357 \mathrm{C}>\mathrm{T} ; 542 \mathrm{C}>\mathrm{T}, 262 \mathrm{~A}>\mathrm{C} ; 357 \mathrm{C}>\mathrm{T})$ and obtained genomic DNA of 22 individuals who have these alleles with reference to Phase 3 of the 1000 Genomes Project (Table 2). In this study, we experimentally confirmed the nonsynonymous SNPs and their haplotypes (alleles). We also analyzed the encoded enzyme activities by transient expression assays. In addition, we predicted the effect of each nonsynonymous SNP on the protein by several in silico methods.

\section{Results}

Sequence and haplotype determination of FUT2. To survey the nonfunctional alleles of FUT2 in the database, we determined the DNA sequence of the total coding region of the FUT2 gene of 22 individuals who were expected to have uncharacterized alleles according to Erythrogene ${ }^{23}$. We detected all of the registered SNPs without deficiency and excess in respective DNA samples in the database by direct Sanger sequencing of the FUT2 coding region and encountered 17 uncharacterized nonsynonymous SNPs that have not been identified yet: $58 \mathrm{C}>\mathrm{T}, 80 \mathrm{~T}>\mathrm{C}, 205 \mathrm{G}>\mathrm{A}, 262 \mathrm{~A}>\mathrm{C}, 370 \mathrm{G}>\mathrm{A}, 539 \mathrm{G}>\mathrm{A}, 542 \mathrm{C}>\mathrm{T}, 544 \mathrm{G}>\mathrm{A}, 566 \mathrm{~T}>\mathrm{C}, 610 \mathrm{G}>\mathrm{T}, 616 \mathrm{G}>\mathrm{C}$, $715 \mathrm{C}>\mathrm{T}, 856 \mathrm{~T}>\mathrm{C}, 863 \mathrm{C}>\mathrm{T}, 964 \mathrm{~A}>\mathrm{G}$, and $980 \mathrm{C}>\mathrm{A}$. In addition to these, the alleles of $357 \mathrm{C}>\mathrm{T}, 403 \mathrm{C}>\mathrm{T}$, and 950C $>\mathrm{T}$ were also investigated, although $403 \mathrm{C}>\mathrm{T}$ and $950 \mathrm{C}>\mathrm{T}$ themselves have been identified in Latin Americans $\left(S e^{357,403}\right)$ and a Mongolian $\left(s e^{357,950}\right)$, respectively ${ }^{17,19}$. We then determined their haplotypes by subcloning them into plasmids. However, sequencing the clones revealed that the haplotypes of ten of 18 alleles were different from those registered in the database, even when the distance between SNPs was only 154 bp (positions 385 and 539 in HG02130, positions 216 (of $s e^{428}$ ) and 370 in HG04017, Table 2). Among the ten alleles, three uncharacterized nonsynonymous SNPs $(370 \mathrm{G}>\mathrm{A}, 544 \mathrm{G}>\mathrm{A}$, and $863 \mathrm{C}>\mathrm{T}$ ) were found on the nonfunctional allele $s e^{428}$, and 403C $>\mathrm{T}$ and $950 \mathrm{C}>\mathrm{T}$ were found on another chromosome (Table 2). Accordingly, we performed functional analyses of the 13 alleles shown in Table 3. Haplotyping revealed that $863 \mathrm{C}>\mathrm{T}$ was on two different alleles, 357C>T; 856T>C; 863C>T (HG03973 (Indian Telugu in the UK)) and 428G >A (plus 4 additional SNPs); 863C $>$ T (NA18908 (Yoruba in Ibadan)) (Table 2).

Functional analyses of candidates of non-secretor alleles. To determine whether each uncharacterized FUT2 allele encodes a functional Se enzyme or not, we ligated each allele into the mammalian expression vector pcDNA3.1, then transfected it into COS-7 cells. The cell surface $\mathrm{H}$ antigen was examined by flow cytometry using a monoclonal antibody to $\mathrm{H}$ type 1-4 (1E3) ${ }^{24}$. We performed five independent transient expression experiments, and the representative result for each allele was shown in Fig. 1. The expression levels of $\mathrm{H}$ antigens on cell surface are shown in Table 3. The percentage of $\mathrm{H}$ antigen-positive cells transfected with pcDNA3.1 


\begin{tabular}{|c|c|c|c|c|}
\hline \multirow[b]{2}{*}{ Coriell No } & \multirow[b]{2}{*}{ Allele in database (Erythrogene) } & \multicolumn{2}{|c|}{ Experimentally determined alleles } & \multirow[b]{2}{*}{ Attribution } \\
\hline & & Target allele & Other allele & \\
\hline HG00701* & $80 \mathrm{~T}>\mathrm{C} ; 357 \mathrm{C}>\mathrm{T} ; 385 \mathrm{~A}>\mathrm{T}$ & $80 \mathrm{~T}>\mathrm{C} ; 357 \mathrm{C}>\mathrm{T}$ & $s e^{357,385}$ & Southern Han Chinese \\
\hline HG01121** & $357 \mathrm{C}>\mathrm{T} ; 403 \mathrm{C}>\mathrm{T} ; 950 \mathrm{C}>\mathrm{T}$ & $357 \mathrm{C}>\mathrm{T} ; 950 \mathrm{C}>\mathrm{T}$ & $357 \mathrm{C}>\mathrm{T} ; 403 \mathrm{C}>\mathrm{T}$ & Colombian in Medellin \\
\hline HG01705 & $357 \mathrm{C}>\mathrm{T} ; 964 \mathrm{~A}>\mathrm{G}$ & $357 \mathrm{C}>\mathrm{T} ; 964 \mathrm{~A}>\mathrm{G}$ & $\mathrm{Se}$ & Iberian populations in Spain \\
\hline HG02130* & $357 \mathrm{C}>\mathrm{T} ; 385 \mathrm{~A}>\mathrm{T}$; 539G $>\mathrm{A}$ & $357 \mathrm{C}>\mathrm{T} ; 539 \mathrm{G}>\mathrm{A}$ & $s e^{357,385}$ & Kinh in Ho Chi Minh City \\
\hline HG02345* & $357 \mathrm{C}>\mathrm{T} ; 610 \mathrm{G}>\mathrm{T}$ & $610 \mathrm{G}>\mathrm{T}$ & $S e^{357}$ & Peruvian in Lima \\
\hline HG03279* & $40 \mathrm{~A}>\mathrm{G} ; 357 \mathrm{C}>\mathrm{T} ; 616 \mathrm{G}>\mathrm{C}$ & $40 \mathrm{~A}>\mathrm{G} ; 616 \mathrm{G}>\mathrm{C}$ & $S e^{357}$ & Esan from Nigeria \\
\hline HG03681 & $357 \mathrm{C}>\mathrm{T} ; 715 \mathrm{C}>\mathrm{T}$ & $357 \mathrm{C}>\mathrm{T} ; 715 \mathrm{C}>\mathrm{T}$ & $s e^{\text {del }}$ & Sri Lankan Tamil in the UK \\
\hline HG03973 & $357 \mathrm{C}>\mathrm{T} ; 856 \mathrm{~T}>\mathrm{C} ; 863 \mathrm{C}>\mathrm{T}$ & $357 \mathrm{C}>\mathrm{T} ; 856 \mathrm{~T}>\mathrm{C} ; 863 \mathrm{C}>\mathrm{T}$ & $s e^{428}$ & Indian Telugu in the UK \\
\hline HG04017*** & $370 \mathrm{G}>\mathrm{A}$ & $370 \mathrm{G}>\mathrm{A}$ on $s e^{428}$ & wild & Indian Telugu in the UK \\
\hline NA11920 & $58 \mathrm{C}>\mathrm{T} ; 357 \mathrm{C}>\mathrm{T}$ & $58 \mathrm{C}>\mathrm{T} ; 357 \mathrm{C}>\mathrm{T}$ & $S e^{357}$ & $\begin{array}{l}\text { Utah residents CEPH with } \\
\text { Northern and Western European } \\
\text { ancestry }\end{array}$ \\
\hline NA18626* & $357 \mathrm{C}>\mathrm{T} ; 566 \mathrm{~T}>\mathrm{C}$ & $566 \mathrm{~T}>\mathrm{C}$ & $S e^{357}$ & Han Chinese in Beijing \\
\hline NA18908** & $481 \mathrm{G}>\mathrm{A} ; 863 \mathrm{C}>\mathrm{T}$ & $481 \mathrm{G}>\mathrm{A}$ & $863 \mathrm{C}>\mathrm{T}$ on $s e^{428}$ & Yoruba in Ibadan \\
\hline NA18951 & \multirow{3}{*}{$357 \mathrm{C}>\mathrm{T} ; 980 \mathrm{C}>\mathrm{A}$} & $357 \mathrm{C}>\mathrm{T} ; 980 \mathrm{C}>\mathrm{A}$ & $s e^{357,385}$ & Japanese in Tokyo \\
\hline NA18974 & & & & Japanese in Tokyo \\
\hline NA19063 & & & & Japanese in Tokyo \\
\hline NA19067* & $357 \mathrm{C}>\mathrm{T} ; 385 \mathrm{~A}>\mathrm{T} ; 980 \mathrm{C}>\mathrm{A}$ & $357 \mathrm{C}>\mathrm{T} ; 980 \mathrm{C}>\mathrm{A}$ & $s e^{357,385}$ & Japanese in Tokyo \\
\hline NA19625*** & $357 \mathrm{C}>\mathrm{T} ; 544 \mathrm{G}>\mathrm{A} ; 771 \mathrm{G}>\mathrm{A}$ & $544 \mathrm{G}>\mathrm{A} ; 771 \mathrm{G}>\mathrm{A}$ on $s e^{428}$ & $S e^{357}$ & African ancestry in Southwest USA \\
\hline NA20520 & \multirow{3}{*}{$205 \mathrm{G}>\mathrm{A} ; 357 \mathrm{C}>\mathrm{T}$} & \multirow{3}{*}{$205 \mathrm{G}>\mathrm{A} ; 357 \mathrm{C}>\mathrm{T}$} & $s e^{428}$ & Toscani in Italy \\
\hline NA20531 & & & $s e^{428}$ & Toscani in Italy \\
\hline NA20532 & & & $S e^{357}$ & Toscani in Italy \\
\hline NA20805 & $357 \mathrm{C}>\mathrm{T} ; 542 \mathrm{C}>\mathrm{T}$ & $357 \mathrm{C}>\mathrm{T} ; 542 \mathrm{C}>\mathrm{T}$ & $s e^{428}$ & Toscani in Italy \\
\hline NA20891 & $262 \mathrm{~A}>\mathrm{C} ; 357 \mathrm{C}>\mathrm{T}$ & $262 \mathrm{~A}>\mathrm{C} ; 357 \mathrm{C}>\mathrm{T}$ & $S e^{357}$ & Gujarati Indians in Houston \\
\hline
\end{tabular}

Table 2. DNA samples and relationship between FUT2 alleles on database and experimentally determined. Note: Asterisks represents samples whose experimentally determined FUT2 haplotype was different from that in the Erythrogene database. ${ }^{*}$ Functional analysis was performed. ${ }^{*}$ Functional analysis was not performed because it was already characterized. ${ }^{* *}$ Functional analysis was not performed because target SNP was on $s e^{428}$.

\begin{tabular}{|c|c|c|c|c|c|c|c|c|c|}
\hline Allele & $\begin{array}{l}\text { Expression level } \\
( \pm \text { SD }) \mathbf{n}=5\end{array}$ & $\begin{array}{l}\text { Luciferase } \\
\text { activity }\left(\times 10^{6}\right. \\
\text { RLU) }( \pm S D) \\
n=5\end{array}$ & Rs No & $\begin{array}{l}\text { Amino acid } \\
\text { change }\end{array}$ & MutationTester & $\begin{array}{l}\text { MutationAssessor } \\
\text { (score) }\end{array}$ & $\begin{array}{l}\text { Polyphen2 ( } \\
\text { score) }\end{array}$ & SIFT (score) & Allele \\
\hline $80 \mathrm{~T}>\mathrm{C} ; 357 \mathrm{C}>\mathrm{T}$ & $25.79(5.43)$ & $2.33(0.25)$ & rs199854717 & M27T & $\mathrm{P}$ & $\mathrm{N}(-0.835)$ & $\mathrm{B}(0.000)$ & $\mathrm{T}(0.16)$ & $S e^{80,357}$ \\
\hline $357 \mathrm{C}>\mathrm{T} ; 964 \mathrm{~A}>\mathrm{G}$ & $19.57(2.34)$ & $2.99(0.19)$ & rs546134946 & $\mathrm{I} 322 \mathrm{~V}$ & $\mathrm{D}$ & $\mathrm{M}(2.990)$ & $\mathrm{P}(0.961)$ & $\mathrm{A}(0.00)$ & $S e^{357,964}$ \\
\hline $357 \mathrm{C}>\mathrm{T} ; 539 \mathrm{G}>\mathrm{A}$ & $23.99(3.69)$ & $3.13(0.11)$ & rs571045256 & R180Q & $\mathrm{P}$ & $\mathrm{N}(0.620)$ & $\mathrm{B}(0.026)$ & $\mathrm{T}(0.29)$ & $\mathrm{Se}^{357,539}$ \\
\hline \begin{tabular}{l|l}
$610 G>T$ \\
\end{tabular} & $0.63(0.36)$ & $4.45(0.46)$ & rs373601796 & G204W & $\mathrm{D}$ & $\mathrm{M}(3.005)$ & $\mathrm{P}(1.000)$ & $\mathrm{A}(0.00)$ & $s e^{610}$ \\
\hline $40 \mathrm{~A}>\mathrm{G} ; 616 \mathrm{G}>\mathrm{C}$ & $21.32(2.75)$ & $3.67(0.39)$ & rs146094646 & V206L & $\mathrm{P}$ & $\mathrm{L}(1.680)$ & $\mathrm{B}(0.172)$ & $\mathrm{A}(0.00)$ & $S e^{40,616}$ \\
\hline $357 \mathrm{C}>\mathrm{T} ; 715 \mathrm{C}>\mathrm{T}$ & $20.45(7.38)$ & $3.22(0.39)$ & rs564523135 & R239W & $\mathrm{D}$ & $\mathrm{M}(2.915)$ & $\mathrm{P}(1.000)$ & $\mathrm{A}(0.05)$ & $\mathrm{Se}^{357,715}$ \\
\hline $\begin{array}{l}357 \mathrm{C}>\mathrm{T} ; \\
856 \mathrm{~T}>\mathrm{C} ; 863 \mathrm{C}>\mathrm{T}\end{array}$ & $0.68(0.27)$ & $3.02(0.50)$ & & & & & & & $s e^{357,856,863}$ \\
\hline \multicolumn{10}{|c|}{ Alleles generated by mutagenesis } \\
\hline $357 \mathrm{C}>\mathrm{T} ; 856 \mathrm{~T}>\mathrm{C}$ & $0.63(0.28)$ & $1.53(0.42)$ & rs537571802 & $\mathrm{Y} 286 \mathrm{H}$ & $\mathrm{D}$ & $\mathrm{M}(3.005)$ & $\mathrm{P}(1.000)$ & A $(0.00)$ & \\
\hline $357 \mathrm{C}>\mathrm{T} ; 863 \mathrm{C}>\mathrm{T}$ & $7.98(0.55)$ & $2.31(0.74)$ & rs146216418 & T288M & $\mathrm{P}$ & $\mathrm{L}(1.445)$ & $\mathrm{P}(0.993)$ & $\mathrm{A}(0.00)$ & \\
\hline $58 \mathrm{C}>\mathrm{T} ; 357 \mathrm{C}>\mathrm{T}$ & $24.31(3.82)$ & $2.95(0.24)$ & rs201010975 & R20W & $\mathrm{P}$ & M (2.915) & $\mathrm{P}(1.000)$ & $\mathrm{A}(0.02)$ & $S e^{58,357}$ \\
\hline $566 \mathrm{~T}>\mathrm{C}$ & $9.28(0.99)$ & $1.39(0.35)$ & rs200698586 & V189A & $\mathrm{D}$ & M (3.005) & $\mathrm{P}(1.000)$ & $\mathrm{A}(0.00)$ & $S e^{566}$ \\
\hline $357 \mathrm{C}>\mathrm{T} ; 980 \mathrm{C}>\mathrm{A}$ & $20.32(2.06)$ & $1.40(0.27)$ & rs139058715 & S327Y & $\mathrm{P}$ & $\mathrm{M}(1.995)$ & $\mathrm{P}(0.989)$ & $\mathrm{A}(0.00)$ & $\mathrm{Se}^{357,980}$ \\
\hline $\begin{array}{l}205 \mathrm{G}>\mathrm{A} \\
357 \mathrm{C}>\mathrm{T}\end{array}$ & $19.27(9.62)$ & $2.19(0.11)$ & rs143120145 & $\mathrm{A} 69 \mathrm{~T}$ & $\mathrm{D}$ & $\mathrm{M}(3.005)$ & $\mathrm{P}(1.000)$ & $\mathrm{A}(0.00)$ & $S e^{205,357}$ \\
\hline $357 \mathrm{C}>\mathrm{T} ; 542 \mathrm{C}>\mathrm{T}$ & $21.69(1.50)$ & $1.75(0.23)$ & rs138954645 & P181L & $\mathrm{D}$ & $\mathrm{M}(2.810)$ & $\mathrm{P}(0.973)$ & $\mathrm{A}(0.00)$ & $\mathrm{Se}^{357,542}$ \\
\hline $262 \mathrm{~A}>\mathrm{C} ; 357 \mathrm{C}>\mathrm{T}$ & $2.03(0.43)$ & $2.58(0.53)$ & rs532253708 & M88L & $\mathrm{P}$ & $\mathrm{M}(3.005)$ & $\mathrm{P}(0.988)$ & $\mathrm{A}(0.00)$ & $s e^{262,357}\left(\mathrm{Se}^{w}\right)$ \\
\hline
\end{tabular}

Table 3. Evaluation of candidates for nonfunctional FUT2 alleles by expression of cell surface $\mathrm{H}$ antigens or in silico analysis of the nonsynonymous SNP. Luciferase activities are presented by Relative Light Unit (RLU). $\mathrm{P}$ and $\mathrm{D}$ represent polymorphism and disease-causing, respectively (MutationTester). N, M, and L represent neutral, medium and low, respectively (MutationAssessor). B and P represent benign and probably damaging, respectively (Polyphen2). T and A represent tolerated and affect protein function, respectively (SIFT). 

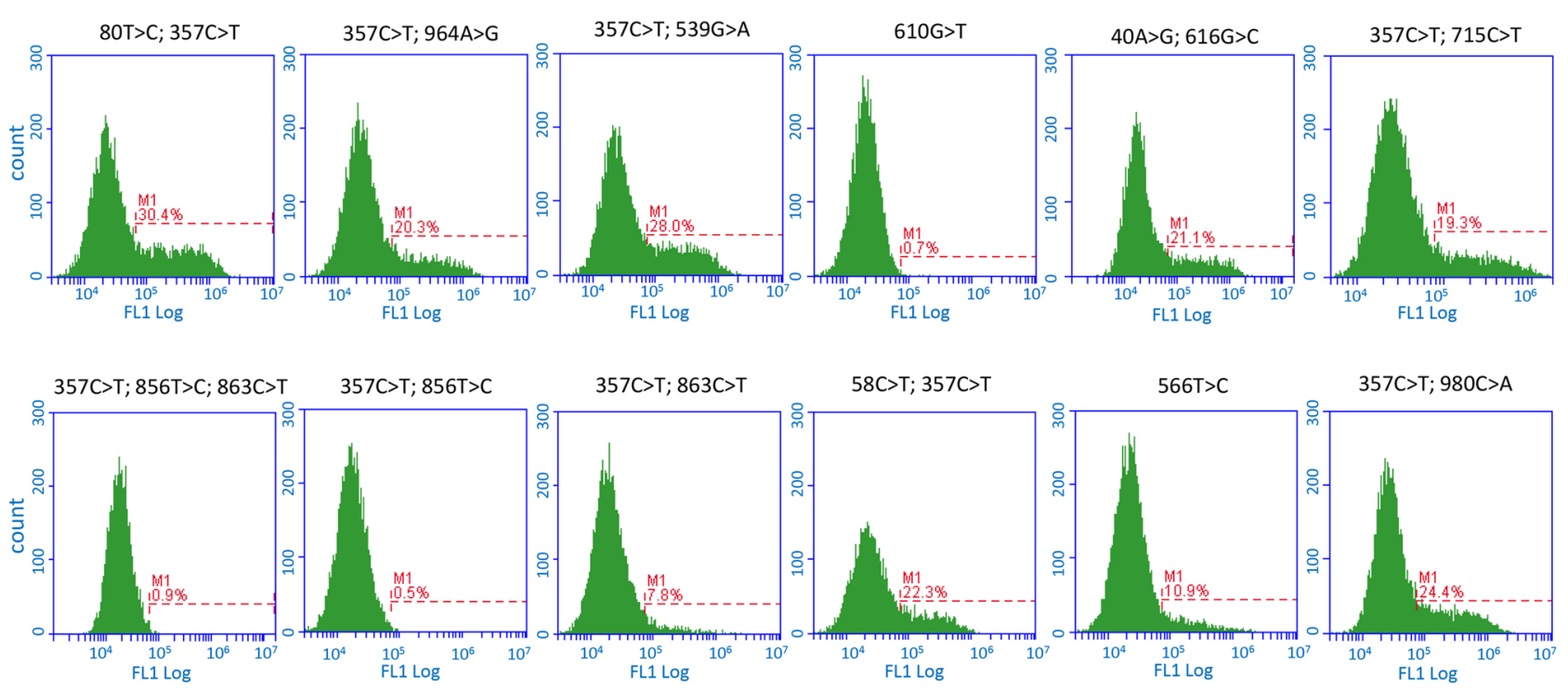

$357 \mathrm{C}>\mathrm{T} ; 980 \mathrm{C}>\mathrm{A}$
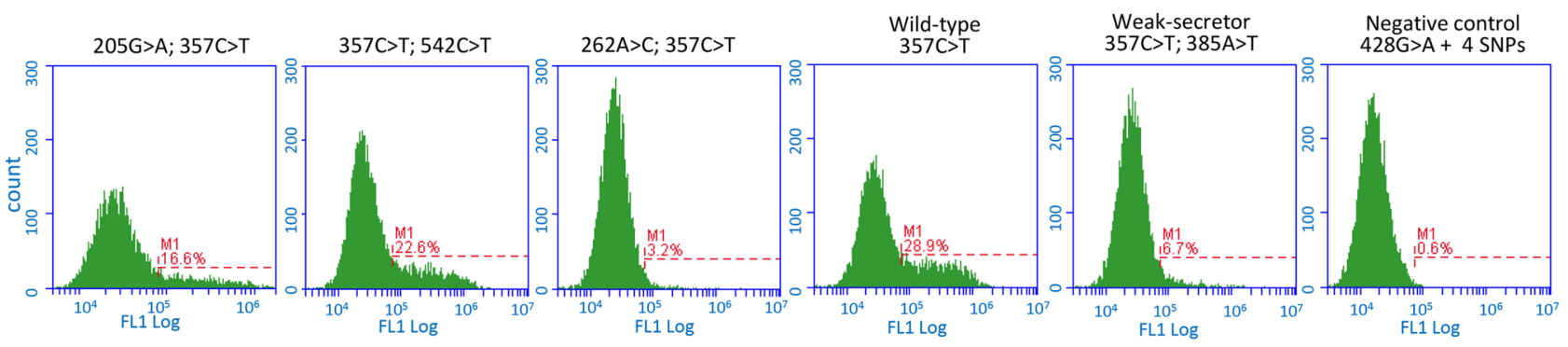

Figure 1. Expression of $\mathrm{H}$ antigens in the COS-7 cells transfected with various FUT2 constructs. The FUT2 allele containing uncharacterized SNP(s) of the FUT2, Se $e^{357}$ (wild-type allele), $s e^{357,385}$ (weak-secretor allele), or $s e^{428}$ (negative control) subcloned into pcDNA3.1(+) plasmids was transfected into COS-7 cells. After 2 days of culture, the cells were incubated with 1E3 antibody, followed by incubation with FITC-conjugated goat anti-mouse IgM secondary antibody, and expression of $\mathrm{H}$ antigen on the cell surface was monitored by flow cytometry.

ligated with the FUT2 of $80 \mathrm{~T}>\mathrm{C} ; 357 \mathrm{C}>\mathrm{T}, 964 \mathrm{~A}>\mathrm{G} ; 357 \mathrm{C}>\mathrm{T}, 357 \mathrm{C}>\mathrm{T} ; 539 \mathrm{G}>\mathrm{A}, 40 \mathrm{~A}>\mathrm{G} ; 616 \mathrm{G}>\mathrm{C}, 357 \mathrm{C}>\mathrm{T}$; $715 \mathrm{C}>\mathrm{T}, 58 \mathrm{C}>\mathrm{T} ; 357 \mathrm{C}>\mathrm{T}, 357 \mathrm{C}>\mathrm{T} ; 980 \mathrm{C}>\mathrm{A}, 205 \mathrm{G}>\mathrm{A} ; 357 \mathrm{C}>\mathrm{T}$, and $357 \mathrm{C}>\mathrm{T} ; 542 \mathrm{C}>\mathrm{T}$ were almost identical to those ligated with the positive control of $S e^{357}$ (wild-type allele, $26.22 \pm 5.06 \%$ ). On the other hand, the percentage of pcDNA3.1 ligated with FUT2 of 566T $>C(9.28 \pm 0.99 \%)$ was less than half of the positive control but higher than that of $s e^{357,385}$ (weak-secretor allele, $4.86 \pm 0.76 \%$ ), while that of $262 \mathrm{~A}>\mathrm{C} ; 357 \mathrm{C}>\mathrm{T}(2.03 \pm 0.43 \%)$ was lower than that of $s e^{357,385}$. In the same experimental condition, expression of the $\mathrm{H}$ antigen on cells transfected with pcDNA3.1-FUT2 of $610 \mathrm{G}>\mathrm{T}$ or $357 \mathrm{C}>\mathrm{T} ; 856 \mathrm{~T}>\mathrm{C} ; 863 \mathrm{C}>\mathrm{T}$ was almost undetectable as was that of $s e^{428}(0.68 \pm 0.19 \%$, Table 3$)$.

Determination of causal SNP of FUT2-357C $>\mathrm{T} ; 856 \mathrm{~T}>\mathrm{C} ; 863 \mathrm{C}>\mathrm{T}$ for inactivation of the encoded enzyme. As mentioned above, the expression study suggested that FUT2 of 357C $>\mathrm{T} ; 856 \mathrm{~T}>\mathrm{C} ; 863 \mathrm{C}>\mathrm{T}$ was a nonfunctional allele. However, this allele contained two nonsynonymous SNPs, 856T $>\mathrm{C}$ and $863 \mathrm{C}>\mathrm{T}$, and it was unclear which SNP was involved in inactivation of the Se enzyme. We generated FUT2 of 357C $>\mathrm{T} ; 856 \mathrm{~T}>\mathrm{C}$ and FUT2 of 357C $>$ T; $863 \mathrm{C}>\mathrm{T}$ by in vitro mutagenesis and performed transient expression and flow cytometry. As shown in Table 3, 856T $>\mathrm{C}$ completely impaired and $863 \mathrm{C}>\mathrm{T}$ somewhat impaired the activity.

Estimation of significance of uncharacterized nonsynonymous SNPs. In addition to the transient expression study, we predicted the possible impacts of 14 amino acid substitutions on the functions of encoded proteins using four software programs.

The results of predictions were not always consistent with those of expression experiments (Table 3). When FUT2 of $610 \mathrm{G}>\mathrm{T}$, of $357 \mathrm{C}>\mathrm{T} ; 856 \mathrm{~T}>\mathrm{C} ; 863 \mathrm{C}>\mathrm{T}$, and of $262 \mathrm{~A}>\mathrm{C} ; 357 \mathrm{C}>\mathrm{T}$ are considered to be nonfunctional alleles and the others functional, the ratio of estimated mismatch was $42.9 \%, 64.3 \%, 57.1 \%$, and $64.3 \%$ by MutationTaster, MutationAssessor, PolyPhen-2, and SIFT, respectively. Of 14 SNPs, the predicted effects were matched for all software and experiments for M38T, R191Q, G215W, and Y297H, while they were completely mismatched for I333V, R250W, V200A, A80T, and P192L (Table 3). The software generally tended to overestimate the impacts of the nonsynonymous SNPs we tested here. 


\section{Discussion}

Recently, public databases are available that provide genetic variation data, and websites dedicated to various purposes using these data are also accessible. The 1000 Genomes Project Phase 3 provides a list of variants and haplotypes of 2,504 individuals from 26 populations using a combination of low-coverage whole-genome sequencing, deep exome sequencing, and dense microarray genotyping ${ }^{23}$. One study reported that phasing and imputation for rare variants are unreliable, which likely reflects the limited sample size of the project data ${ }^{25}$. In this study, we observed discordance between the haplotypes on Erythrogene from the 1000 Genomes project and those experimentally phased haplotypes for ten out of 18 haplotypes. Actually, the FUT2 alleles we investigated have frequencies of 0.02 to $0.06 \%$ in the studied 2504 samples of 26 populations on 1000 Genomes, that is, one to three of 5008 alleles. That may be the reason for the discordance, but it should not be ignored in association studies on secretor status when its prevalence is at a certain level in the target populations. Previously, we identified $400 \mathrm{G}>\mathrm{A}$ (rs370886251) of a functional FUT2 allele $S e^{400}$ in a Samoan population with a frequency of $2.1 \%$ (one of 48 alleles) ${ }^{26}$. This allele was also observed in Indonesians at 1.2\% (two of 166 alleles) ${ }^{27}$. In addition, we encountered it in six New Guinean populations with the relatively high prevalences of $10.6 \%$ (42 of 114 alleles) to $36.8 \%$ ( 7 of 66 alleles $)^{28}$. These results suggest that $400 \mathrm{G}>\mathrm{A}$ is distributed in Oceania and neighboring countries. However, 400G $>\mathrm{A}$ is not listed in 1000 Genomes and subsequently Erythrogene. These observations raise the possibility that some of the nonsynonymous SNPs we examined here may be present at unignorable frequencies in certain populations ${ }^{25}$.

The best way to evaluate the activity of the Se enzyme may be consideration in conjunction with phenotypic data using red blood cells or saliva as specimens. In the Lewis blood group, $\operatorname{Le}(a-b+)$ is identified as a secretor, $\operatorname{Le}(\mathrm{a}+\mathrm{b}-)$ as a non-secretor, and $\operatorname{Le}(\mathrm{a}+\mathrm{b}+)$ as a weak-secretor ${ }^{29}$. We can also measure the amount of $\mathrm{ABO}$ substances in saliva. However, we could not perform phenotyping and can only speculate on the secretor status based on the genetic information. In this study, we estimated the activity of the enzyme encoded by FUT2 alleles of interest by transient expression and subsequent flow cytometry for detection of cell surface $\mathrm{H}$ antigens expressed. In addition, the impacts of the target missense SNPs on the Se enzyme are also deduced by four software programs because we experienced a discrepancy between the results obtained by in vitro and those by in silico analyses ${ }^{17-19}$. In the results, we also observed discrepancies for six to nine out of 14 SNPs, while all of the SNPs reside in the catalytic domain. Previously, we identified a FUT2 allele with 357C $>$ T; 685G $>$ A in a Bangladeshi secretor individual with genotype of 357C $>\mathrm{T} ; 685 \mathrm{G}>\mathrm{A} / 302 \mathrm{C}>\mathrm{T}$. The $\alpha(1,2)$ fucosyltransferase activity of the enzyme encoded by FUT2 of $357 \mathrm{C}>\mathrm{T} ; 685 \mathrm{G}>\mathrm{A}$ was $8 \%$ of that of the wild-type allele ${ }^{26}$. From this observation, we categorized FUT2 of 566T $>\mathrm{C}$ as a secretor allele $\left(\mathrm{Se}^{566}\right)$ and that of $262 \mathrm{~A}>\mathrm{C} ; 357 \mathrm{C}>\mathrm{T}$ as a weak secretor allele $\left(s e^{262,357}, S e^{w}\right)$, while the secretor status phenotypes were unknown and the 566T $>\mathrm{C}$ substitution seemed to partially impair enzyme activity (Table 3 ).

In this study, we used an academically isolated monoclonal antibody, but the $\mathrm{H}$ antigens could be evaluated by the commercially available UEA-1 lectin (Ulex europaeus agglutinin I) ${ }^{19,21,24}$. In addition, as mentioned earlier, the sequence of the FUT2 is coded solely in exon 2. This makes it easy to clone the coding sequence or determine the haplotype of the coding polymorphisms.

Considering all the factors mentioned above, experimental procedures such as the haplotyping by cloning and evaluation of activity of the Se enzyme are desirable for FUT2. However, the 1000 Genome Project provides a valuable catalogue of human genetic variation, and the Erythrogene focus on blood group systems also enables easy reference to the FUT2 alleles from the 1000 Genome Project. Actually, the existences of listed SNPs themselves were completely confirmed in the indicated samples. In addition, the software programs for prediction of the functional impacts of amino acid substitutions are valuable tools, especially for the proteins whose functions are hard to estimate experimentally. Accordingly, there is no doubting the helpfulness of these databases or software programs.

\section{Conclusion}

We identified two non-secretor alleles $\left(s e^{610}\right.$ and $\left.s e^{357,856,863}\right)$ and one weak secretor allele $\left(s e^{262,357}\right)$ in samples in the 1000 Genome Project. Experimental phasing and expression studies are desirable for analysis of FUT2.

\section{Materials and methods}

The study protocol was approved by the ethical committees of Kurume University School of Medicine (No. 342).

DNA samples. Twenty-two genomic DNAs (HG00701, HG01121, HG01705, HG02130, HG02345, HG03279, HG03681, HG03973, HG04017 of the 1000 Genomes project, NA11920 of CEPH/Utah Pedigree 1423, NA18626, NA18908, NA18951, NA18974, NA19063, NA19067, NA19625, NA20520, NA20531, NA20532, NA20805, NA20891 of International HapMap Project) were purchased from the Coriell Institute for Medical Research (Camden, NJ, USA) (Table 2).

PCR amplification of coding region of FUT2 and sequence analysis. The coding regions of FUT2 were amplified and directly sequenced as described previously ${ }^{17}$.

Haplotype determination of FUT2. To determine the haplotypes of individuals who were heterozygous at two or more positions, we cloned PCR products into a plasmid and sequenced the clones as described previously ${ }^{17}$. 
Transient expression study and evaluation of impact of nonsynonymous SNPs of FUT2. To evaluate the significance of each of uncharacterized allele, a transient expression experiment was performed as described previously ${ }^{17}$. The FUT2 alleles containing each SNP concerned, 357C $>\mathrm{T}$ ( $S e^{357}$ : wild-type allele), $171 \mathrm{~A}>\mathrm{G}$ and $216 \mathrm{C}>\mathrm{T}$ and $428 \mathrm{G}>\mathrm{A}$ and $739 \mathrm{G}>\mathrm{A}$ and $960 \mathrm{~A}>\mathrm{G}\left(s^{428}\right.$ : nonsecretor allele) or $357 \mathrm{C}>\mathrm{T}$ and $385 \mathrm{~A}>\mathrm{T}$ $\left(s e^{357,385}\right.$ : weak-secretor allele) were inserted into pcDNA3.1 $(+)$ vectors. Three $\mu \mathrm{g}$ of each construct together with $100 \mathrm{ng}$ of the pGL3 Promoter was transfected into $5 \times 10^{5} \mathrm{COS}-7$ cells (African green monkey kidney fibroblastlike cell) by means of TransIT-X2 (Mirus Bio LLC, Madison, WI).After 2 days of culture, the cells were incubated with 1E3 antibody for $\mathrm{H}$ type 1-4, followed by incubation with FITC-conjugated goat anti-mouse IgM (Bethyl Laboratories, Montgomery, TX) secondary antibody, and expression of $\mathrm{H}$ antigen on the cell surface was monitored by flow cytometry (BD Accuri C6, Becton Dickinson, Franklin Lakes, NJ) as described previously ${ }^{18,24}$. The experiments were performed five times. About $1 \times 10^{5}$ cells were lysed and the firefly luciferase activity was assayed using ONE-Glo Luciferase Assay System (Promega, Madison, WI) and the similar transfection efficiency in each experiment was confirmed by the intensity of luciferase light (Table 3).

Prediction of impacts of nonsynonymous SNPs on Se enzyme. The effect of each nonsynonymous SNP of FUT2 on the function of the enzyme were predicted using four free software programs, MutationTaster (http://www.mutationtaster.org/) ${ }^{30}$, MutationAssessor (http://mutationassessor.org/r3/) $)^{31}$, PolyPhen-2 (http:// genetics.bwh.harvard.edu/pph2/) ${ }^{32}$, and Sorting Intolerant From Tolerant (SIFT) (http://sift.jcvi.org/) 33 .

Introduction of reverse substitution in allele containing $357 \mathrm{C}>\mathrm{T} ; 856 \mathrm{~T}>\mathrm{C} ; 863 \mathrm{C}>\mathrm{T}$. Because functional analysis showed one allele containing $357 \mathrm{C}>\mathrm{T}$; $856 \mathrm{~T}>\mathrm{C}$; $863 \mathrm{C}>\mathrm{T}$ to be a nonfunctional allele, sitespecific mutagenesis of the plasmid DNA was performed using a Q5 Site-Directed Mutagenesis Kit (New England Biolabs Japan Inc., Tokyo, Japan) to determine which substitution is responsible for inactivation of the enzyme. The primer set used for reverse substitution at 856 (C to T) was 5'-CTG GGC CGC ATA CCT CAT GGG-3' (forward primer, 846-866 bp of FUT2, position 856 and 863 are underlined) and 5'-ATC CCG AAC GTC CCA ATG GTC ATG-3' (reverse primer, 822-845 bp of FUT2). That for 863 (T to C) was 5'-GCA CAC CTC ACG GGC GGA GAC-3' (forward primer, 853-873 bp, position 856 and 863 are underlined) and 5'-GGC CCA GAT CCC GAA CGT-3' (reverse primer, 835-852 bp of FUT2). The plasmid pcDNA3.1(+) containing FUT2 of $357 \mathrm{C}>\mathrm{T} ; 856 \mathrm{~T}>\mathrm{C} ; 863 \mathrm{C}>\mathrm{T}$ was used as a template. All procedures were performed according to the manufacturer's protocol. The cycling conditions were an initial denaturation at $98^{\circ} \mathrm{C}$ for $30 \mathrm{~s}$, followed by 25 cycles of denaturation at $98^{\circ} \mathrm{C}$ for $10 \mathrm{~s}$, annealing at $70^{\circ} \mathrm{C}$ (for 856 reverse substitution) or $72{ }^{\circ} \mathrm{C}$ (for 863 reverse substitution) for $20 \mathrm{~s}$, and extension at $72{ }^{\circ} \mathrm{C}$ for $3 \mathrm{~min}$, followed by final extension at $72{ }^{\circ} \mathrm{C}$ for $2 \mathrm{~min}$. The sequences of the isolated clones were confirmed. Finally, we obtained two constructs, pcDNA3.1(+) containing FUT2 of $357 \mathrm{C}>\mathrm{T}$; $856 \mathrm{~T}>\mathrm{C}$ and $357 \mathrm{C}>\mathrm{T} ; 863 \mathrm{C}>\mathrm{T}$.

Received: 10 December 2020; Accepted: 27 January 2021

Published online: 04 February 2021

\section{References}

1. Clausen, H. \& Hakomori, S. ABH and related histo-blood group antigens; immunochemical differences in carrier isotypes and their distribution. Vox Sang 56, 1-20. https://doi.org/10.1111/j.1423-0410.1989.tb03040.x (1989).

2. Oriol, R., Danilovs, J. \& Hawkins, B. R. A new genetic model proposing that the Se gene is a structural gene closely linked to the H gene. Am. J. Hum. Genet. 33, 421-431 (1981).

3. Koda, Y. et al. Contrasting patterns of polymorphisms at the ABO-secretor gene (FUT2) and plasma alpha(1,3)fucosyltransferase gene (FUT6) in human populations. Genetics 158, 747-756 (2001).

4. Ferrer-Admetlla, A. et al. A natural history of FUT2 polymorphism in humans. Mol. Biol. Evol. 26, 1993-2003. https://doi. org/10.1093/molbev/msp108 (2009).

5. Kelly, R. J., Rouquier, S., Giorgi, D., Lennon, G. G. \& Lowe, J. B. Sequence and expression of a candidate for the human Secretor blood group alpha( 1,2$)$ fucosyltransferase gene (FUT2). Homozygosity for an enzyme-inactivating nonsense mutation commonly correlates with the non-secretor phenotype. J. Biol. Chem. 270, 4640-4649 (1995).

6. Koda, Y., Soejima, M., Wang, B. \& Kimura, H. Structure and expression of the gene encoding secretor-type galactoside 2-alphaL-fucosyltransferase (FUT2). Eur. J. Biochem. 246, 750-755 (1997).

7. Soejima, M. \& Koda, Y. Molecular mechanisms of Lewis antigen expression. Leg Med. (Tokyo) 7, 266-269. https://doi.org/10.1016/j. legalmed.2004.12.003 (2005).

8. Lindesmith, L. et al. Human susceptibility and resistance to Norwalk virus infection. Nat. Med. 9, 548-553. https://doi.org/10.1038/ nm860 (2003).

9. Imbert-Marcille, B. M. et al. A FUT2 gene common polymorphism determines resistance to rotavirus A of the P[8] genotype. J. Infect. Dis. 209, 1227-1230. https://doi.org/10.1093/infdis/jit655 (2014).

10. McGovern, D. P. et al. Fucosyltransferase 2 (FUT2) non-secretor status is associated with Crohn's disease. Hum. Mol. Genet. 19, 3468-3476. https://doi.org/10.1093/hmg/ddq248 (2010).

11. Parmar, A. S. et al. Association study of FUT2 (rs601338) with celiac disease and inflammatory bowel disease in the Finnish population. Tissue Antigens 80, 488-493. https://doi.org/10.1111/tan.12016 (2012).

12. Henry, S., Mollicone, R., Lowe, J. B., Samuelsson, B. \& Larson, G. A second nonsecretor allele of the blood group alpha(1,2)fucosyltransferase gene (FUT2). Vox Sang 70, 21-25. https://doi.org/10.1111/j.1423-0410.1996.tb00991.x (1996).

13. Chang, J. G. et al. Molecular analysis of secretor type alpha(1,2)-fucosyltransferase gene mutations in the Chinese and Thai populations. Transfusion 39, 1013-1017. https://doi.org/10.1046/j.1537-2995.1999.39091013.x (1999).

14. Yu, L. C. et al. Polymorphism and distribution of the Secretor alpha(1,2)-fucosyltransferase gene in various Taiwanese populations. Transfusion 41, 1279-1284. https://doi.org/10.1046/j.1537-2995.2001.41101279.x (2001).

15. Storry, J. R. et al. Identification of six new alleles at the FUT1 and FUT2 loci in ethnically diverse individuals with Bombay and Para-Bombay phenotypes. Transfusion 46, 2149-2155. https://doi.org/10.1111/j.1537-2995.2006.01045.x (2006).

16. Yip, S. P., Lai, S. K. \& Wong, M. L. Systematic sequence analysis of the human fucosyltransferase 2 (FUT2) gene identifies novel sequence variations and alleles. Transfusion 47, 1369-1380. https://doi.org/10.1111/j.1537-2995.2007.01280.x (2007). 
17. Soejima, M., Nakajima, T., Fujihara, J., Takeshita, H. \& Koda, Y. Genetic variation of FUT2 in Ovambos, Turks, and Mongolians. Transfusion 48, 1423-1431. https://doi.org/10.1111/j.1537-2995.2008.01710.x (2008).

18. Soejima, M. \& Koda, Y. Genetic variation of FUT2 in a Peruvian population: identification of a novel LTR-mediated deletion and characterization of 4 nonsynonymous single-nucleotide polymorphisms. Transfusion 59, 2415-2421. https://doi.org/10.1111/ trf.15298 (2019).

19. Soejima, M. \& Koda, Y. FUT2 polymorphism in Latin American populations. Clin. Chim. Acta 505, 1-5. https://doi.org/10.1016/j. cca.2020.02.011 (2020).

20. Koda, Y., Soejima, M., Liu, Y. \& Kimura, H. Molecular basis for secretor type alpha(1,2)-fucosyltransferase gene deficiency in a Japanese population: A fusion gene generated by unequal crossover responsible for the enzyme deficiency. Am. J. Hum. Genet. 59, 343-350 (1996).

21. Silva, L. M. et al. Infection-associated FUT2 (Fucosyltransferase 2) genetic variation and impact on functionality assessed by in vivo studies. Glycoconj. J. 27, 61-68. https://doi.org/10.1007/s10719-009-9255-8 (2010).

22. Sudmant, P. H. et al. An integrated map of structural variation in 2,504 human genomes. Nature 526, 75-81. https://doi.org/10.1038/ nature15394 (2015).

23. Möller, M., Jöud, M., Storry, J. R. \& Olsson, M. L. Erythrogene: a database for in-depth analysis of the extensive variation in 36 blood group systems in the 1000 Genomes Project. Blood Adv. 1, 240-249. https://doi.org/10.1182/bloodadvances.2016001867 (2016).

24. Nakajima, T., Yazawa, S., Miyazaki, S. \& Furukawa, K. Immunochemical characterization of anti-H monoclonal antibodies obtained from a mouse immunized with human saliva. J. Immunol. Methods 159, 261-267 (1993).

25. Belsare, S. et al. Evaluating the quality of the 1000 genomes project data. BMC Genom. 20, 620. https://doi.org/10.1186/s1286 4-019-5957-x (2019).

26. Pang, H. et al. Two distinct Alu-mediated deletions of the human ABO-secretor (FUT2) locus in Samoan and Bangladeshi populations. Hum. Mutat. 16, 274. https://doi.org/10.1002/1098-1004(200009)16:3\%3c274::AID-HUMU20\%3e3.0.CO;2-I (2000).

27. Pang, H. et al. Polymorphism of the human ABO-Secretor locus (FUT2) in four populations in Asia: Indication of distinct Asian subpopulations. Ann. Hum. Genet. 65, 429-437. https://doi.org/10.1017/S0003480001008788 (2001).

28. Koda, Y. et al. DNA sequence variation of the human ABO-secretor locus (FUT2) in New Guinean populations: possible early human migration from Africa. Hum. Genet. 113, 534-541. https://doi.org/10.1007/s00439-003-1013-6 (2003).

29. Henry, S. et al. Molecular basis for erythrocyte Le $(a+b+)$ and salivary ABH partial-secretor phenotypes: expression of a FUT2 secretor allele with an A->T mutation at nucleotide 385 correlates with reduced alpha $(1,2)$ fucosyltransferase activity. Glycoconj. J. 13, 985-993. https://doi.org/10.1007/bf01053194 (1996).

30. Schwarz, J. M., Rödelsperger, C., Schuelke, M. \& Seelow, D. MutationTaster evaluates disease-causing potential of sequence alterations. Nat. Methods 7, 575-576. https://doi.org/10.1038/nmeth0810-575 (2010).

31. Reva, B., Antipin, Y. \& Sander, C. Predicting the functional impact of protein mutations: Application to cancer genomics. Nucleic Acids Res. 39, e118. https://doi.org/10.1093/nar/gkr407 (2011).

32. Sunyaev, S. et al. Prediction of deleterious human alleles. Hum. Mol. Genet. 10, 591-597 (2001).

33. Ng, P. C. \& Henikoff, S. Predicting the effects of amino acid substitutions on protein function. Annu. Rev. Genom. Hum. Genet. 7, 61-80. https://doi.org/10.1146/annurev.genom.7.080505.115630 (2006).

\section{Acknowledgements}

We thank Ms. Katherine Ono for the English editing of this manuscript.

\section{Author contributions}

M.S. performed experiments and contributed to the data analysis and drafting of the manuscript. Y.K. planned the experiment, contributed to the data analysis and interpretation, and drafted the paper.

\section{Competing interests}

The authors declare no competing interests.

\section{Additional information}

Correspondence and requests for materials should be addressed to Y.K.

Reprints and permissions information is available at www.nature.com/reprints.

Publisher's note Springer Nature remains neutral with regard to jurisdictional claims in published maps and institutional affiliations.

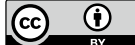

Open Access This article is licensed under a Creative Commons Attribution 4.0 International License, which permits use, sharing, adaptation, distribution and reproduction in any medium or format, as long as you give appropriate credit to the original author(s) and the source, provide a link to the Creative Commons licence, and indicate if changes were made. The images or other third party material in this article are included in the article's Creative Commons licence, unless indicated otherwise in a credit line to the material. If material is not included in the article's Creative Commons licence and your intended use is not permitted by statutory regulation or exceeds the permitted use, you will need to obtain permission directly from the copyright holder. To view a copy of this licence, visit http://creativecommons.org/licenses/by/4.0/.

(C) The Author(s) 2021 